G

OPEN ACCESS

Citation: Patiño LDF, Vélez M, Velásquez SP, Vera GCY, Vélez V, Marín IC, Ramíerez PA, Pemberthy QS, Castrillón ME, Pineda HDA, Hernández G. Colomb Med (Cali). 2020; 51(2):e-4266 http://doi.org/10.25100/cm.v51i2.4266

Received : 02 Apr 2020

Revised : 25 Apr 2020

Accepted : 04 May 2020

Published: 11 May 2020

Keywords:

COVID-19, Coronavirus, Review, Public Health, Quarantine, Health Impact Assessment

Palabras clave:

COVID-19, coronavirus, revisión, salud pública, cuarentena, evaluación del impacto en la salud

Copyright: @ 2020. Universidad del Valle.

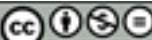

REVIEW

\title{
Non-pharmaceutical interventions for containment, mitigation and suppression of COVID-19 infection
}

\section{Intervenciones no farmacéuticas para la contención, mitigación y supresión de la infección por COVID-19}

\author{
Daniel F. Patiño-Lugo ${ }^{10}$ Marcela Vélez ${ }^{1}$ Pamela Velásauez Salazar ${ }^{1}$ Claudia Yaneth \\ Vera-Giraldo $^{1}$ Viviana Vélez ${ }^{1}$ Isabel Cristina Marín ${ }^{1}$ Paola Andrea Ramírez ${ }^{1}$ \\ Sebastián Pemberthy Quintero ${ }^{1}$ Esteban Castrillón Martínez ${ }^{1}$ Daniel Andrés Pineda \\ Higuita $^{1}$, Gilma Henandez ${ }^{1}$ \\ felipe.patiño@udea.edu.co
}

1.Universidad de Antioquia, Unidad de Evidencia y Deliberación para la toma de DecisionesUNED, Facultad de Medicina, Medellin Colombia

\section{Abstract}

\section{Background:}

The best scientific evidence is required to design effective Non-pharmaceutical interventions to help policymakers to contain COVID-19.

Aim:

To describe which Non-pharmaceutical interventions used different countries and a when they use them. It also explores how Non-pharmaceutical interventions impact the number of cases, the mortality, and the capacity of health systems.

\section{Methods:}

We consulted eight web pages of transnational organizations, 17 of international media, 99 of government institutions in the 19 countries included, and besides, we included nine studies (out of 34 identified) that met inclusion criteria.

\section{Result:}

Some countries are focused on establishing travel restrictions, isolation of identified cases, and high-risk people. Others have a combination of mandatory quarantine and other drastic social distancing measures. The timing to implement the interventions varied from the first fifteen days after detecting the first case to more than 30 days. The effectiveness of isolated non-pharmaceutical interventions may be limited, but combined interventions have shown to be effective in reducing the transmissibility of the disease, the collapse of health care services, and mortality. When the number of new cases has been controlled, it is necessary to maintain social distancing measures, self-isolation, and contact tracing for several months. The policy decision-making in this time should be aimed to optimize the opportunities of saving lives, reducing the collapse of health services, and minimizing the economic and social impact over the general population, but principally over the most vulnerable. The timing of implementing and lifting interventions could have a substantial effect on those objectives. 


\section{Conflict of Interest:}

The authors declare that they have no competing interests

\section{Acknowledgments}

The authors want to thank Ivan Dario Flórez and Gabriel Jaime Otálvaro for their important comments and suggestions. They also thank Cristian David Santa Escobar for his contribution in the graphic representation of the results

\section{Corresponding author:}

Daniel F. Patiño-Lugo. Facultad de Medicina, Universidad de Antioquia. Postal address: Carrera $51 \mathrm{D}$ \# 62-29 oficina MUA 302, Medellín, Colombia. Tel: +57 (4) 2196060.. e-mail: felipe.patiño@ udea.edu.co

\section{Remark}

\section{Why was this study conducted?}

To know what non-pharmaceutical interventions (Non-pharmaceutical interventions) have different countries adopted for containment, mitigation, or suppression of COVID-19 pandemic and at what time they were implemented. To review the evidence on the impact of Nonpharmaceutical interventions on containment, mitigation, or suppression of the pandemic.

\section{What were the most relevant results of the study?}

Some countries are mainly focused on establishing travel restrictions, isolation of identified cases, and high-risk people. Others have a more intense combination of drastic social distancing measures like mandatory quarantine measures for the entire population and closure of all educational centers. Some of the countries have implemented drastic social distancing measures in the first fifteen days after detecting the first case, other countries have taken more than 30 days. The effectiveness of isolated Non-pharmaceutical interventions may be limited, but combined interventions have shown to have a high impact in reducing the transmissibility of the disease, the collapse of health care services, and mortality. When the number of new cases has been controlled, it is necessary to maintain social distancing measures. Testing, contact tracing, and quarantine of suspected cases could be the main strategies after the relaxation of drastic social distancing Non-pharmaceutical interventions.

\section{What do these results contribute?}

The evidence synthesized might inform the policy decision-making regarding the control of COVID-19 disease.

\section{Resumen}

\section{Antecedentes:}

Se requiere la mejor evidencia científica para diseñar intervenciones no farmacológicas efectivas para ayudar a los formuladores de políticas a contener COVID-19.

\section{Objetivo:}

Describir qué intervenciones no farmacológicas utilizaron diferentes países y cuándo las implementaron. También explora cómo las intervenciones no farmacológicas afectan el número de casos, la mortalidad y la capacidad de los sistemas de salud.

\section{Métodos:}

Consultamos ocho páginas web de organizaciones transnacionales, 17 de medios internacionales, 99 de instituciones gubernamentales en los 19 países incluidos, y además, incluimos nueve estudios (de 34 identificados) que cumplían con los criterios de inclusión.

\section{Resultados:}

Algunos países implementaron restricciones de viaje, aislamiento de casos identificados y personas de alto riesgo. Otros combinaron varias medidas más drásticas de distanciamiento social. El tiempo para implementar las intervenciones varió desde los primeros quince días después de detectar el primer caso hasta más de 30 días. La efectividad de las intervenciones no farmacológicas combinadas ha demostrado ser efectivas para reducir la transmisibilidad de la enfermedad, el colapso de los servicios de salud y la mortalidad. Cuando se controle el número de casos nuevos, es necesario mantener medidas de distanciamiento social, autoaislamiento y rastreo de contactos durante varios meses. La toma de decisiones políticas en este momento debe tener como objetivo optimizar las oportunidades de salvar vidas, reducir el colapso de los servicios de salud y minimizar el impacto económico y social sobre la población en general, pero principalmente sobre los más vulnerables. 


\section{Introduction}

Coronavirus disease 2019 (COVID-19) is a new, rapidly emerging infectious disease, which constitutes a major global health threat ${ }^{1}$. On January 30th, 2020, the World Health Organization (WHO) declared the outbreak a global health emergency ${ }^{2}$, while Colombia did it on March 12th ${ }^{3}$.

The virus SARS-CoV-2 appears to have high transmissibility, the basic reproduction number (R0) range from 2.8 to 5.5 , in the absence of full quarantine and social distancing measures, in comparison to the average R0 for seasonal influenza viruses which is about $1.8^{4}$.

In past experiences, like the 1918-19 H1N1 influenza pandemic, no effective interventions or vaccines were available to treat or prevent the disease; this has taught us that in these circumstances, a variety of non-pharmaceutical interventions (Non-pharmaceutical interventions) are successful at reducing case numbers ${ }^{4}$. Non-pharmaceutical interventions include isolating ill persons, contact tracing, quarantine of exposed persons, social distancing, travel restrictions, school, churches and workplace closure, and cancellation of mass gathering events $^{4-9}$. Those interventions have shown to be effective ways to respond to the outbreak when implemented early in the epidemic (4-6). Past epidemics have also shown that while the interventions remained in place, mortality is reduced; however, "transmission rebounded once controls are lifted" ${ }^{4}$.

Three groups of Non-pharmaceutical interventions strategies have been recognized, 1) containment, 2) mitigation, and 3) suppression ${ }^{6,7}$. Containment interventions are those implemented when the first cases are detected in order to interrupt the transmission of the disease, prevent its spread and give time to the healthcare system to make the preparations for attending patients, and waiting for the development of vaccines and effective interventions ${ }^{9}$. Mitigation interventions are used when the number of cases increases and the possibility of finding a relationship between cases is complicated, mitigation is not aimed to interrupt transmission completely, but to reduce the health impact of an epidemic over the mortality and the collapse of the health system ${ }^{4,10}$. And suppression is intended to reduce the average number of secondary cases each case generates ${ }^{4}$.

According to the Imperial College, suppression carries enormous social and economic costs, which may themselves have a significant impact on health and well-being in the short and longer-term. Mitigation will never be able to protect those at risk from severe disease or death entirely, and the resulting mortality may, therefore, still be high ${ }^{4}$.

In China, three major Non-pharmaceutical interventions have been implemented to control the spread and reduce the outbreak size of COVID-19 ${ }^{9}$. First, inter-city travel bans and the establishment of a cordon sanitaire of Wuhan and surrounding cities in Hubei Province ${ }^{9,11-13}$. Second, measures for improving the screening, contact tracing, identification, diagnosis, isolation, and reporting of suspected ill persons and confirmed cases ${ }^{9,14}$. And third, implementing inner-city travel and contact restrictions, which included limiting individual social contact, using personal hygiene and protective measures, and increasing the physical distance between those who have COVID-19 and those who do not ${ }^{9,15}$. The Chinese government also encouraged people to stay at home as much as possible, canceled or postponed large public events and mass gatherings, and closed libraries, museums, and workplaces ${ }^{8,9}$.

The progressive spread of the disease has allowed many countries to anticipate that a pandemic is approaching ${ }^{9,16}$. In the case of Colombia, some local governments, as well as the national government, rapidly and drastically implemented a quarantine in all the national territory, as well as other Non-pharmaceutical interventions aimed at the contention, suppression, and mitigation of the COVID-19 disease. 
The best available scientific evidence is required to design effective Non-pharmaceutical interventions and disseminate the knowledge urgently to help policymakers assess the potential benefits and costs of Non-pharmaceutical interventions to contain COVID-19 outbreaks. It is essential to describe how different countries implement Non-pharmaceutical interventions, and at what point of the epidemic. It is also necessary to explore how those Non-pharmaceutical interventions have impacted the number of cases, the mortality, and the capacity of health care facilities to deliver healthcare services. There are still crucial knowledge gaps on the effectiveness of different interventions to adequately justify the preparation, implementation, or cancellation of various Non-pharmaceutical interventions, policymakers across the World need evidence as to the combination and timings of each, which remains lacking.

\section{Materials and Methods}

A rapid evidence synthesis focused on identifying Non-pharmaceutical interventions implemented in the city of Wuhan and 19 countries (i.e., Argentina, Australia, Brazil, Canada, Chile, China, Colombia, Cuba, Germany, Iran, Italy, Japan, Mexico, Norway, Russia, South Korea, Spain, United Kingdom, and the United States) was carried out. Three criteria were applied to select the countries and territories, 1) a comparatively high number of cases, 2) a political or social particularity that allows the understanding of different types of Nonpharmaceutical interventions or different pace in their implementation; and 3) balance between countries in Europe, Asia, and North, Central, and South America.

Eight web pages of transnational organizations, 17 webpages of international magazines and newspapers, and 99 webpages of governmental institutions in the 19 countries included were searched from January $1^{\text {st }}$ to March $25^{\text {th }}, 2020$. Additionally, the databases Medline and Embase were searched for studies evaluating the effectiveness of Non-pharmaceutical interventions for the containment, suppression, and mitigation of COVID-19 (Appendix 1 with the search sources).

Official documents and media articles were used to determine the date when different countries implemented Non-pharmaceutical interventions. The eligibility criteria of academic papers were that the article was focused on exploring the effectiveness and impact of Nonpharmaceutical interventions on the containment, suppression, or mitigation of COVID-19, with no language, neither study design restrictions. Eligible studies included observational studies (cohorts, time series, series report), simulations studies, and health system or political system guidance.

Quality assessment of observational studies was performed with the Johana Briggs criteria for appraisal. In contrast, simulation studies were not formally quality assessed. Still, a judgement was provided according to the completeness of variables to perform the simulation, the strength of the assumptions, and the quality of the description of the statistical procedure. All stages of the review process were performed by one researcher and checked by a second.

Information about the number of new cases and new deaths caused by COVID-19 in the countries and territories chosen was reached from the John Hopkins Center for Systems Science and Engineering after realizing that its dashboard has more updated information than the situation reports of $\mathrm{WHO}^{1}$. The first case reported in each country was documented from official sources or from WHO, with this information, we determined how many days elapsed between the first case reported and the NPI decision taken by the government. The number of days to make the decision was used to develop a timeline of events, a heat map, and a joint figure that represents new cases day by day and the point in which the Non-pharmaceutical interventions were decided. The heat map was developed with R software ${ }^{17}$. 


\section{Results}

All countries have implemented several Non-pharmaceutical interventions to control COVID-19 infection. However, there is variability in the amount and type of interventions. In countries like Brazil, Canada, Mexico, and Russia, we identified few interventions, and none of them were among the most drastic measures of social distancing, for example, Mexico has only implemented the closure of schools and colleges ${ }^{18}$. These countries have focused mainly on avoiding the entry of cases by using travel restrictions and isolating the identified cases and high-risk people.

Another group of countries applied several interventions, including one of the drastic social distancing ones. South Korea, United Kingdom, and the United States, for example, have implemented more drastic social distancing interventions combined with rules of detection, contact tracing, and isolation of cases and contacts. Notably, South Korean is recognized for the rapid implementation of a mass case detection strategy ${ }^{19}$, while recently in some of the States in the United States have begun the implementation of social distancing measures ${ }^{20}$.

The third group of countries has applied an intense combination of drastic interventions for containment, mitigation, and suppression of infection. Argentina, Chile, China, Colombia, Italy, Spain, all implemented mandatory quarantine for the entire population, after closing schools and universities, canceling all events that concentrated more than 200 people and suspending public transportation for all who do not carry out essential work for infection control. In addition, they have also employed case isolation and contact tracing, borders closings, and some are implementing mass case detection.

\section{Non-pharmacological interventions according to implementation time}

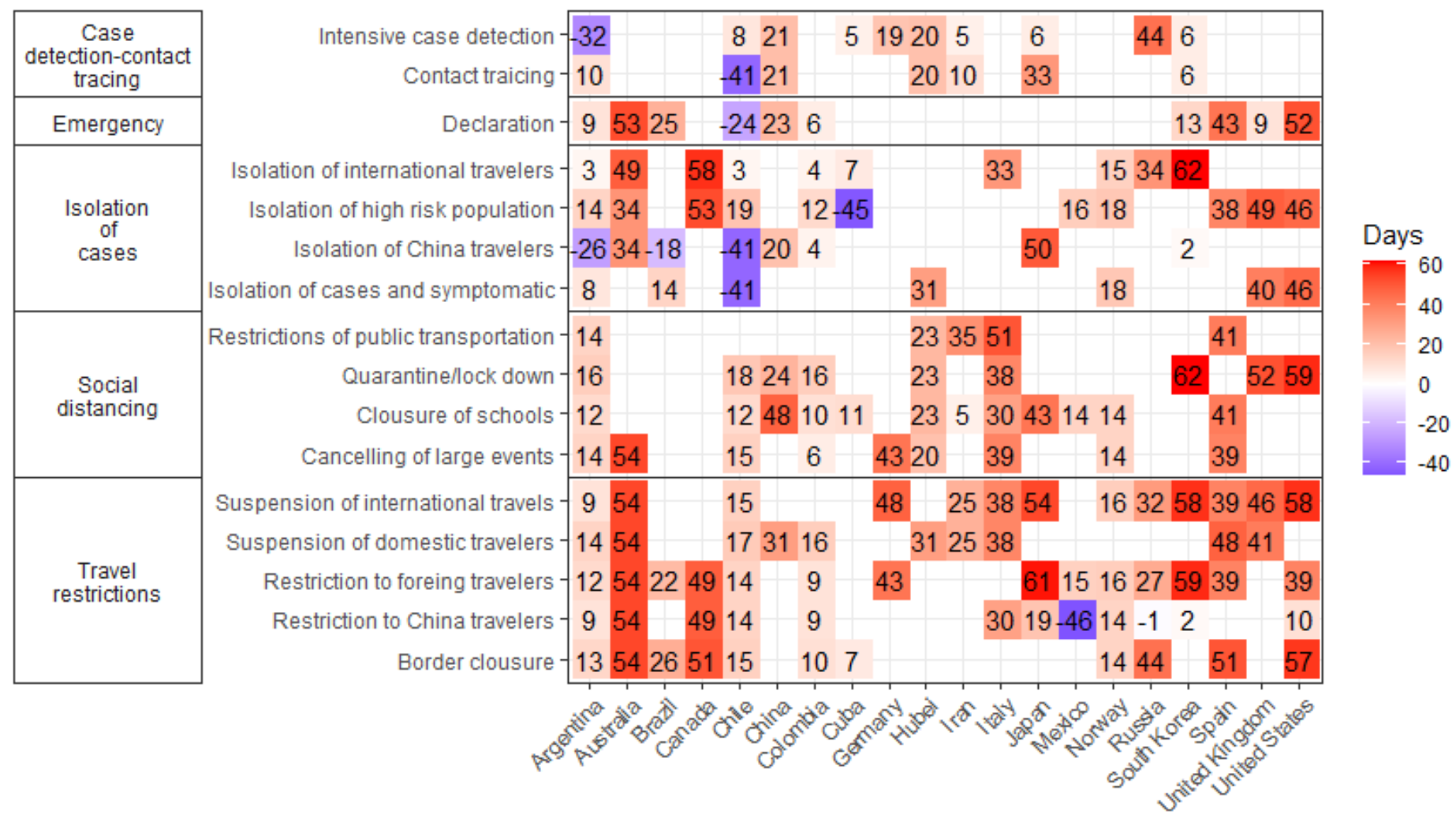

Figure 1. Heat map of Non-pharmaceutical interventions and number of days in which they were implement them after the first case of COVID-19 
Non-pharmaceutical interventions for containment, mitigation and suppression of COVID-19 infection

Table 1. Non-pharmaceutical interventions and number of days to implement them after the first case of COVID-19 (as march 28 of 2020 )

\begin{tabular}{|c|c|c|c|c|c|c|c|c|c|c|c|c|c|c|c|c|c|c|c|c|}
\hline Countries/first case date & Hubei & China & Japan & Korea & $\begin{array}{l}\text { United } \\
\text { States }\end{array}$ & Australia & Canada & Germany & Spain & Italia & Russia & $\begin{array}{l}\text { United } \\
\text { Kingdom }\end{array}$ & Iran & Brazil & Norway & México & Chile & Argentina & Colombia & Cuba \\
\hline & $31 / 12 / 19$ & $31 / 12 / 2019$ & $15 / 01 / 20$ & $20 / 01 / 20$ & $21 / 01 / 20$ & $26 / 01 / 20$ & $27 / 01 / 20$ & $27 / 01 / 20$ & $31 / 01 / 20$ & $31 / 01 / 20$ & $1 / 02 / 20$ & $1 / 02 / 20$ & $20 / 02 / 20$ & $26 / 02 / 20$ & $27 / 02 / 20$ & $29 / 02 / 203$ & $3 / 03 / 20$ & $3 / 03 / 20$ & $6 / 03 / 20$ & $13 / 03 / 20$ \\
\hline \multicolumn{21}{|c|}{ Measure } \\
\hline Emergency declaration & & 23 & & 13 & 52 & 53 & & & 43 & & & 9 & & 25 & & & -24 & 9 & 6 & \\
\hline \multicolumn{21}{|l|}{$\begin{array}{l}\text { Population level social } \\
\text { distancing }\end{array}$} \\
\hline Quarantine & 23 & 24 & & $62^{*}$ & 59 & & & & & 38 & & 52 & & & & & 18 & 16 & 16 & \\
\hline Closing schools and universities & 23 & 48 & 43 & & & & & & 41 & 30 & & & 5 & & 14 & 14 & 12 & 12 & 10 & 11 \\
\hline Canceling of large events & 20 & & & & & 54 & & 43 & 39 & 39 & & & & & 14 & & 15 & 14 & 6 & \\
\hline $\begin{array}{l}\text { Suspension of public transpor- } \\
\text { tation }\end{array}$ & 23 & & & & & & & & 41 & 51 & & & 35 & & & & & 14 & & \\
\hline \multicolumn{21}{|l|}{ Isolation of cases and contacts } \\
\hline \multicolumn{21}{|l|}{ Isolation of cases and contacts } \\
\hline Isolation of travelers from china & & 20 & 50 & 2 & & 34 & & & & & & & & -18 & & & -41 & -26 & 4 & \\
\hline $\begin{array}{l}\text { Isolation of travelers from other } \\
\text { countries }\end{array}$ & & & & 62 & & 49 & 58 & & & 33 & 34 & & & & 15 & & 3 & 3 & 4 & 7 \\
\hline Isolation of high-risk population & & & & & 46 & 34 & 53 & & 38 & & & 49 & & & 18 & 16 & 19 & 14 & 12 & -45 \\
\hline $\begin{array}{l}\text { Isolation of cases or symptomatic } \\
\text { people }\end{array}$ & 31 & & & & 46 & & & & & & & 40 & & 14 & 18 & & -41 & 8 & & \\
\hline
\end{tabular}

s or symptomatic

Travel restrictions

Entry restrictions for foreigners

(China)

Entry restrictions for foreigners

(Others)

Closure of border

International travel restrictions

Inter-city travel restrictions

$31 \quad 31$

$\begin{array}{lllll}19 & 2 & 10 & 54 & 49\end{array}$

Early case detection and contact

Intensive early case detection

$\begin{array}{cccc}20 & 21 & 6 & 6 \\ 20 & 21 & 33 & 6\end{array}$

Contac tracing

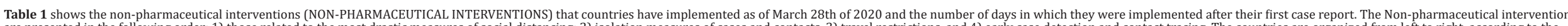

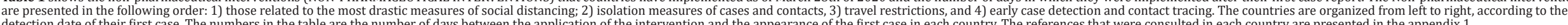
* The social distancing strategy recently used in South Korea is not mandatory as in other countries. However, the campaign is quite comprehensive, so we decided to put it in this box.

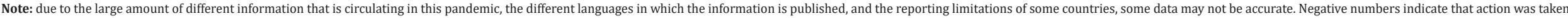
before the first case came. For example, Chile declared a state of alert on February 8, which is 24 days before the first case. 
Table 2. Impact of non-pharmaceutical interventions for the control of COVID-19 infection

\begin{tabular}{|c|c|c|c|}
\hline No-Pharmaceutical Intervention & Impact & $\begin{array}{l}\text { \# of studies } \\
\text { addressing the } \\
\text { intervention }\end{array}$ & Type of study \\
\hline Combination of interventions & High & 7 & $\begin{array}{l}1 \text { policy guidance } \\
2 \text { cohort studies } \\
1 \text { rapid systematic review } \\
1 \text { time series study } \\
2 \text { simulations }\end{array}$ \\
\hline Isolation of cases & High & 3 & $\begin{array}{l}1 \text { policy guidance } \\
2 \text { simulations }\end{array}$ \\
\hline Early detection of cases & High & 2 & $\begin{array}{l}1 \text { policy guidance } \\
1 \text { simulation }\end{array}$ \\
\hline Contact tracing & High & 1 & 1 simulation \\
\hline Quarantine of contacts & High & 2 & $\begin{array}{l}1 \text { cohort study } \\
1 \text { policy guidance }\end{array}$ \\
\hline $\begin{array}{l}\text { Suspension of public transportation } \\
1 \text { cohort study }\end{array}$ & High & 2 & $\begin{array}{l}1 \text { rapid systematic review } \\
1 \text { cohort study }\end{array}$ \\
\hline Canceling of large events & High & 2 & $\begin{array}{l}1 \text { rapid systematic review } \\
1 \text { cross-sectional study }\end{array}$ \\
\hline $\begin{array}{l}\text { Maintaining social distancing interventions for at least } 6 \\
\text { months after the outbreak }\end{array}$ & High & 2 & 2 simulations \\
\hline Self-isolation of symptomatic people & Moderately high & 2 & $\begin{array}{l}1 \text { policy guidance } \\
1 \text { simulation }\end{array}$ \\
\hline $\begin{array}{l}\text { Isolation of people older than } 70 \text { years } \\
\text { Work at home strategies }\end{array}$ & $\begin{array}{l}\text { Moderate } \\
\text { Moderate }\end{array}$ & $\begin{array}{l}1 \\
1\end{array}$ & $\begin{array}{l}1 \text { simulation } \\
1 \text { policy guidance }\end{array}$ \\
\hline Social distancing & Moderately low & 3 & $\begin{array}{l}2 \text { simulations } \\
1 \text { rapid systematic review }\end{array}$ \\
\hline Inner-city travel restrictions & Moderately low & 2 & $\begin{array}{l}1 \text { policy guidance } \\
1 \text { simulation }\end{array}$ \\
\hline Inter-city travel restrictions & Moderately low & 3 & $\begin{array}{l}1 \text { policy guidance } \\
1 \text { cohort study } \\
1 \text { cross-sectional study }\end{array}$ \\
\hline Closure of schools and daycares & Moderately low & 2 & $\begin{array}{l}1 \text { policy guidance } \\
1 \text { simulation }\end{array}$ \\
\hline Quarantine of people traveling from territories affected & Low & 1 & 1 cohort study \\
\hline Contact reduction & Low & 1 & 1 simulation \\
\hline Closure of borders & Low & 1 & 1 policy guidance \\
\hline Procedures for detecting cases in the airports & Low & 1 & 1 policy guidance \\
\hline
\end{tabular}




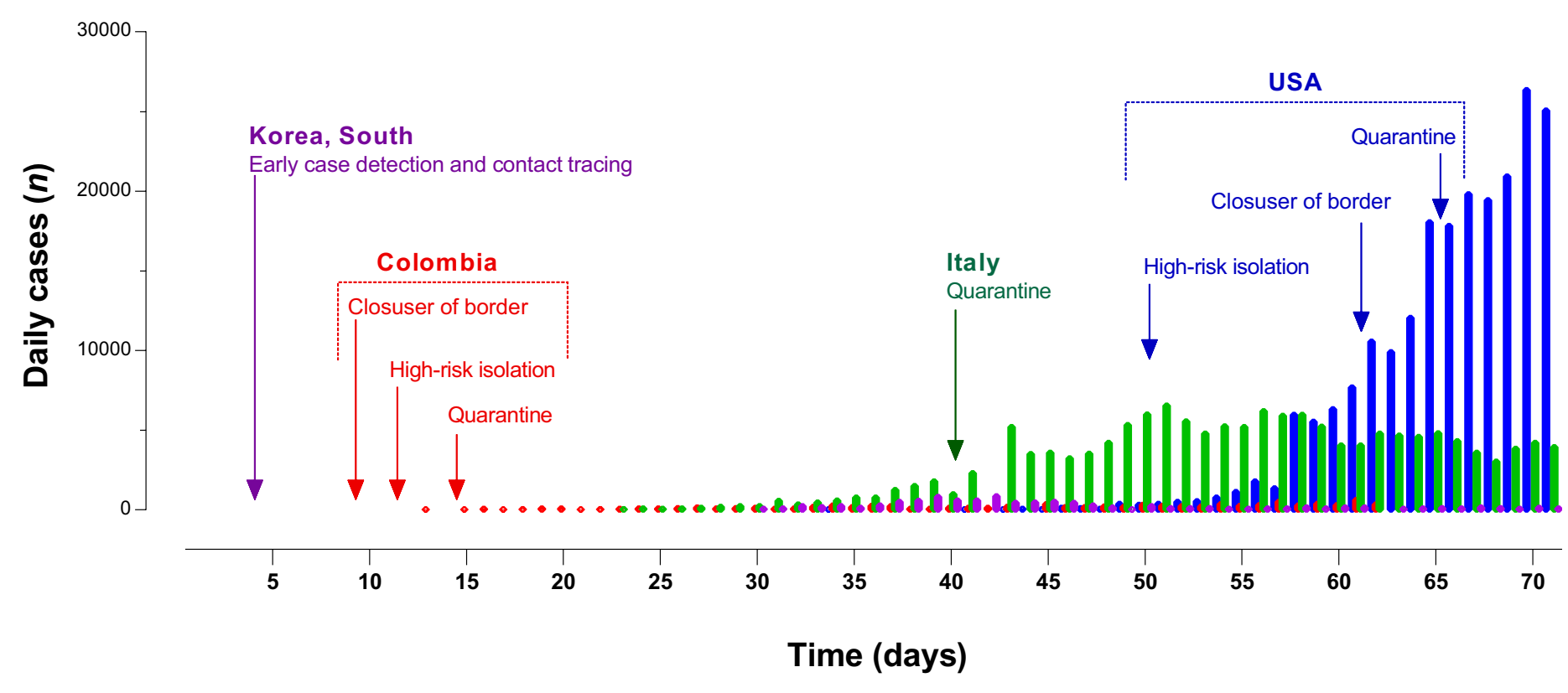

USA

Colombia

Italy

Korea, South

Figure 2. Number of new COVID-19 cases and day of implementation of some Non-pharmaceutical interventions

Regarding the pace for implementing the strategies, some countries such as Argentina, Chile, and Colombia, which reported the first case in March, implemented interventions in the early fifteen days after the detection of the first case (Table 1 for further details), or even before the notification of the first case, as it is the case of Chile. Argentina, Chile, and Colombia have had the opportunity to anticipate and learn from the policy decision made in other countries, such as China and South Korea, affected as early as December 2019 and January 2020 (Figure 1 that exhibits a heat map of the time to implement the interventions). Countries such as Italy, Spain, and the United States, took more than 30 days to implement drastic measures of social distancing, and they are displaying an extreme situation of the collapse of their health systems. These experiences have served to apprentice countries to making decisions early after the first case is reported (Figure 2 for information about the moment in which some countries have implemented some decisions and the number of new cases they had at that time).

Other Non-pharmaceutical interventions implemented by the countries analyzed include interventions to improve the infrastructure of the health system and strength the human resources capacity (e.g., expand the capacity of beds, enable the use of stadiums and other spaces), strategies aimed at populations at risk (e.g., special measures for the people deprived of liberty), social support interventions (e.g., tax relieves), strategies to support the production of goods and services (e.g., facilitate loans to companies), and strategies for accurate information, timely communication, and support for social distancing (Appendix 2).

\section{Impact of Non-pharmaceutical interventions}

In exploring the effectiveness of non-pharmaceutical interventions on containment, suppression, and mitigation of COVID-19 infection, we included nine over 34 studies identified (one policy guidance, one rapid systematic review, two cohort studies, one time series study, and four simulations) ${ }^{4-6,11-13,21,22}$. Appendix 3 summarizes the findings of these studies.

The effectiveness of any isolated Non-pharmaceutical interventions may be limited, but 
combined interventions have shown to be effective and have a high impact in reducing the transmissibility of the disease, the collapse of health care services, and mortality. Seven of nine studies included explicitly suggest the early implementation of combined and strict interventions; mainly, quarantine, social distancing, suspension of public transportation, early

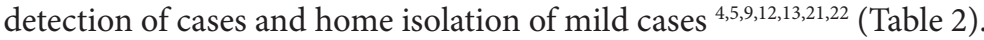

Without the implementation of Non-pharmaceutical interventions, one study in China claims that the number of COVID-19 cases would have a 51-fold increase in Wuhan, a 92fold increase in other Hubei cities, and a 125 -fold increase in other provinces ${ }^{9}$. Combined Non-pharmaceutical interventions might reduce the maximum demand for medical care and mortality by half or even two thirds ${ }^{4}$. A simulation study for the United Kingdom and the United States shows that, in an uncontrolled epidemic, demand for intensive care beds is predicted to exceed as early as the second week of April, with peak demand for care beds of more than 30 times the maximum supply in both countries ${ }^{4}$.

After the peak of the disease, and when the number of new cases has been controlled, it is necessary to maintain social distancing measures, control of public transportation, workat-home strategies, case detection and isolation, and contact tracing. Contact tracing and case isolation are suggested to be highly effective in controlling a new COVID-19 outbreak. However, the probability of control decreases with 1) long delays from onset of symptoms until deciding isolation, 2) few contacts tracked per case, and 3) when the transmission before symptoms increases ${ }^{22}$. In most of the simulation scenarios and from the public health experience of previous epidemics, it is identified that, if the social contact resumes to normal levels, the contagions could increase again. Therefore several Non-pharmaceutical interventions, including social distancing, should be continued for several months, ${ }^{9}$ it is even proposed that restrictive measures should be maintained until a vaccine is available (potentially 18 months or more) since it is predicted that transmission will recover quickly if interventions are relaxed ${ }^{4}$.

When the number of new cases demonstrates the control of the disease, evidence suggests that measures that can be lifted first are border closures, case detection procedures at airports, and the closings of schools and daycares. The evidence also suggests that both the establishment and removal of Non-pharmaceutical interventions depend on several political, social, and cultural factors, not only on the behavior of the disease ${ }^{5,9,21}$.

\section{Discussion}

\section{Summary of the main findings}

We consulted eight web pages of transnational organizations, 17 of international media, 99 of government institutions in the 19 countries included, and besides, we included nine studies (out of 34 identified) that met inclusion criteria. We found that some countries are mainly focused on establishing travel restrictions, isolation of identified cases, and high-risk people. Others have a more intense combination of mandatory quarantine for the entire population, closure of all educational centers, and suspension of public transportation for all those who do not perform essential work. Some of the countries have implemented interventions in the first fifteen days after detecting the first case, while others have taken more than 30 days to implement drastic measures of social distancing. The effectiveness of isolated Nonpharmaceutical interventions may be limited, but combined interventions have shown to be effective and have a high impact in reducing the transmissibility of the disease, the collapse of health care services, and mortality. When the number of new cases has been controlled, it is necessary to maintain social distancing measures, public transportation control, work at home strategies, case detection, self-isolation, and contact tracing for several months. 


\section{Comparison with other studies}

A modeling study made in Colombia to predict the impact of the COVID-19 pandemic according to mitigation measures that have been implemented in the country resonates with our findings that combined interventions could be effective and have a high impact on reducing the transmissibility of the disease. The study of González-Jaramillo et al. ${ }^{(23}$, concludes that the combination of mitigation strategies taken by the Colombian government could reduce the number of patients that would require intensive care units from 36,782 in the scenario of no intervention to 1,176 in the scenario that combines case isolation, home quarantine, and social distancing of people over 70 years old.

Our finding of the need to maintain social distancing measures, control of public transportation, work-at-home strategies, case detection and isolation, and contact tracing has also been supported in the literature. The model developed by Prem et al., suggests that the sudden lifting of interventions could lead to an earlier secondary peak, which could be prevented by relaxing the interventions gradually ${ }^{14}$. In this regard, Colburn suggests that testing, contact tracing, and quarantine of suspected cases could be the main strategies after the relaxation of drastic social distancing Non-pharmaceutical interventions to prevent healthcare system overload. Colburn calls for the incorporation of these strategies into models to allow countries to have a better picture of the testing capacity they will need and to decide if such policies could be successful in suppressing COVID-19 spread in a given country ${ }^{24}$.

Non-pharmaceutical interventions also have adverse effects on individuals, communities, and the national economy. A recent rapid review reported that quarantine could have harmful psychological effects such as post-traumatic stress symptoms, confusion, and anger, which can lead to adverse long-term psychological effects ${ }^{21,25}$. Many articles have highlighted the economic implications that quarantine interventions might have over the economy in 2020; however, the goal at this moment is saving as many lives as our resources allowed $4,5,8,9,12,13,21,26$.

\section{Limitations of this review}

Given the time constraints imposed by the ongoing coronavirus outbreak, we made some critical methodological decisions that need to be considered. The inclusion criteria and the extraction of information of the studies included in this synthesis were applied by one reviewer. In addition, simulation studies were not formally quality assessed.

\section{Conclusion}

The policy decision-making in this time should be aimed to optimize the opportunities of saving lives, reducing the collapse of health services, and minimizing the economic and social impact over the general population, but principally over the most vulnerable. The timing of implementing and lifting interventions is likely to have a substantial effect on those objectives.

\section{References}

1. The Humanitarian Data Exchange. Coronavirus COVID-19 Global Cases. OCHA services; 2020. Cited: 2020 Mar 23. Available from: https://data.humdata.org/dataset/novel-coronavirus-2019-ncov-cases

2. WHO. WHO Director-General's opening remarks at the media briefing on COVID-19-11 March 2020. Geneva, Switzerland; 2020. Available from: https://www.who.int/dg/speeches/detail/who-director-general-sopening-remarks-at-the-media-briefing-on-covid-19---11-march-2020

3. Presidencia de la República. Declaración del estado de emergencia Colombia: Marzo 2017. Presidencia de la República: Colombia; 2020 p. 1-16.

4. Ferguson NM, Laydon D, Nedjati-Gilani G, Imai N, Ainslie K, Baguelin M, et al. Impact of non-pharmaceutical interventions (Non-pharmaceutical interventions) to reduce COVID-19 mortality and healthcare demand. 2020; Imperial College London. pp 20. doi: 10.25561/77482. 
5. ECDC (European Centre for Disease Prevention and Control. Guidelines for the use of non-pharmaceutical measures to delay and mitigate the impact of 2019-nCoV; 2020.

6. Nunan D, Brassey J. What is the evidence for mass gatherings during global pandemics? A rapid summary of best-available evidence. Centre Evidence-Based Medicine, Nuffield Department of Primary Care Health Sciences University of Oxford, Trip Database; 2020;1-8.

7. Hossain MP, Junus A, Zhu X, Jia P, Wen T-H, Pfeiffer D, et al. The effects of border control and quarantine measures on global spread of COVID-19. medRxiv. 2020; Preprint. Doi: 10.1101/2020.03.13.20035261

8. European Centre for Disease Prevention and Control. Considerations relating to social distancing measures in response to the COVID-19 epidemic Scope of this document Key points. Technical report; Stockholm: ECDC; 2020 .

9. Lai S, Ruktanonchai NW, Zhou L, Prosper O, Luo W, Floyd JR, et al. Effect of non-pharmaceutical interventions for containing the COVID-19 outbreak in China. medRxiv. 2020;1(1):1-29. doi: 10.1101/2020.03.03.20029843

10. Wilder-Smith A, Chiew CJ, Lee VJ. Can we contain the COVID-19 outbreak with the same measures as for SARS? Lancet Infect Dis. 2020;3099(20). doi: 10.1016/S1473-3099(20)30129-8

11. Zhang C, Chen C, Shen W, Tang F, LEi H, Xie Y, et al. Impact of population movement on the spread of 2019-nCoV in China. Lancet Infect Dis. 2020; Preprint: 30. doi: 10.2139/ssrn.3546090Z

12. Tian H, Liu Y, Li Y, Wu C-H, Chen B, Kraemer MUG, et al. The impact of transmission control measures during the first 50 days of the COVID-19 epidemic in China. medRxiv Prepr. 2020;1(1):1-29. doi: 10.1101/2020.01.30.20019844

13. Lau H, Khosrawipour V, Kocbach P, Mikolajczyk A, Schubert J, Bania J, et al. The positive impact of lockdown in Wuhan on containing the COVID-19 outbreak in China. J Travel Med. 2020;001(714). doi: 10.1093/ $\mathrm{jtm} / \mathrm{taaa037}$

14. Prem K, Liu Y, Russell T, Kucharski AJ, Eggo RM, Davies N, et al. The effect of control strategies that reduce social mixing on outcomes of the COVID-19 epidemic in Wuhan, China. medRxiv. 2020;2667(20). doi: $10.1101 / 2020.03 .09 .20033050$

15. Chen W, Wang Q, Li YQ, Yu HL, Xia YY, Zhang ML, et al. Early containment strategies and core measures for prevention and control of novel coronavirus pneumonia in China. Zhonghua Yu Fang Yi Xue Za Zhi. 2020;54(3):1-6.

16. Anderson RM, Heesterbeek H, Klinkenberg D, Hollingsworth TD. How will country-based mitigation measures influence the course of the COVID-19 epidemic? Lancet;. 2020;2019(20):1-4. Doi: 10.1016/ S01406736(20)305675

17. Team Rs. RStudio: integrated development for R. RStudio, Inc, Boston, MA. Available from: URL http//www. rstudio.com. 2015;42:14.

18. Gobierno de Mexico. Informe técnico COVID-19 14 MARZO 2020; 2020. Cited: 2020 Mar 28. Available from: https://presidente.gob.mx/informe-tecnico-covid-19-14-marzo-2020/

19. KCDC. Press Release: The updates on COVID-19 in Korea; 2020. Cited: 2020 Mar 28. Available from: https://www.cdc.go.kr/board/board.es?mid=a30402000000\&bid=0030

20. Perfil. Nueva York y California, en cuarentena total por Covid-19. Perfil. 2020; Available from: https://www. perfil.com/noticias/internacional/nueva-york-y-california-en-cuarentena-total-por-covid-19.phtml 
21. Nussbaumer-streit B, Chapman A, Dobrescu Al, Mayr V, Persad E, Klerings I, et al. The effectiveness of quarantine to control the Coronavirus disease 2019: a rapid review. Lancet Glob Heal. 2020; Preprint. doi: $10.2139 /$ ssrn. 3550010

22. Hellewell J, Abbott S, Gimma A, Bosse NI, Jarvis Cl, Russell TW, et al. Feasibility of controlling COVID-19 outbreaks by isolation of cases and contacts. Lancet. 2020; 8(4): e488-e496. doi: 10.1016/S2214109X(20)30074-7

23. González-jaramillo V, González-jaramillo N, Gómez-restrepo C, Palacio-acosta CA, Gómez-lópez A, Franco $\mathrm{OH}$. Proyecciones de impacto de la pandemia COVID-19 en la población colombiana, según medidas de mitigación. Datos preliminares de modelos epidemiológicos para el periodo del 18 de marzo al 18 de abril de 2020. Rev Salud Pública. 2020;(22):1-6.

24. Colbourn T. Comment COVID-19?: extending or relaxing distancing control measures. Lancet. 2020;2667(20):19-20. doi: 10.1016/S2468-2667(20)30072-4

25. Brooks SK, Webster RK, Smith LE, Woodland L, Wessely S, Greenberg N, et al. The psychological impact of quarantine and how to reduce it: Rapid review of the evidence. Lancet. 2020; Preprint. doi: 10.1016/S01406736(20)30460-8

26. Zhang $\mathrm{C}$, Deng $\mathrm{H}$, Zhang $\mathrm{Q}$. The value of early response by surrounding areas of epidemic center hubei during COVID-2019 outbreak in china?: A quasi- experiment analysis. SSRN. 2019; 1-16. doi: 10.2139/ ssrn. $3548372 Z$ 


\section{Appendix 1. Search sources.}

WHO PAHO. WHO Situation Dashboard. https://experience.arcgis.com/experience/685d0ace521648f8a5beeeee1b9125cd

WHO. 2019 Novel Coronavirus (2019nCoV): Strategic preparedness and response plan. 03 de Febrero. https://www.who.int/docs/ default-source/coronaviruse/srp-04022020.pdf

Enfermedad por el Coronavirus (COVID-19). https://www.paho.org/es/temas/coronavirus/enfermedad-por-coronavirus-covid-19

\section{UNION EUROPEA}

Eurosurvelliance. https://www.eurosurveillance.org/content/eurosurveillance/browse

EU Commision COVID-19 Coronavirus data. https://data.europa.eu/euodp/en/data/dataset/covid-19-coronavirus-data/ resource/62eb477f-be00-462a-831a-594095f7306a

Politico. Coronavirus in Europe https://www.politico.eu/coronavirus-in-europe/

ECDC. European Centre for Disease Prevention and Control https://www.ecdc.europa.eu/en

IATA. International Air Transport Association. Government Measures Related to Coronavirus (COVID-19). https://www.iata.org/en/ programs/safety/health/diseases/government-measures-related-to-coronavirus/

Johns Hopkins University and Medicine. Coronavirus Resource Center. Interactive maps and news https:/coronavirus.jhu.edu/

COVID-19 Expert Reality Check. Johns Hopkins Bloomberg School of Public Health. https://www.globalhealthnow.org/2020-02/coronavirus-expert-reality-check\#quammen

Worldometer owned by Dadax. https://www.worldometers.info/coronavirus/

Evidence Aid https://www.evidenceaid.org/coronavirus-resources/

\section{Otros medios de comunicación}

Science Magazine. Mass testing, school closings, lockdowns: Countries pick tactics in 'war' against coronavirus. By Jon Cohen, Kai KupferschmidtMar. 18, 2020 , 11:30 AM. https://www.sciencemag.org/news/2020/03/mass-testing-school-closings-lockdowns-countriespick-tactics-war-against-coronavirus

The Economist. The politics of pandemics. All governments will struggle. Some will struggle more than others. https://www.economist. com/leaders/2020/03/12/the-politics-of-pandemics

Prospect Magazine UK. Coronavirus: Why scientists are divided over the effectiveness of the UK's strategy by Philip Ball / March 16, 2020. https://www.prospectmagazine.co.uk/science-and-technology/coronavirus-uk-herd-immunity-boris-johnson-government-plancure

StateNews. Understanding what works: How some countries are beating back the coronavirus by Helen Branswell March $20,2020$. https://www.statnews.com/2020/03/20/understanding-what-works-how-some-countries-are-beating-back-the-coronavirus/

The NY Times. The Coronavirus Outbreake https://www.nytimes.com/news-event/coronavirus? action=click\&pgtype=Article\&state=d efault\&module=STYLN_coronahub\&variant=show\&region=header\&context=menu

Wikipedia . Resumen de decisiones de los gobiernos. https://en.wikipedia.org/wiki/National_responses_to_the_2019\%E2\%80\%9320_ coronavirus_pandemic 
International restrictions.https://en.wikipedia.org/wiki/Travel_restrictions_related_to_the_2019\%E2\%80\%9320_coronavirus_pandemic

BBC News. Coronavirus pandemic. https://www.bbc.com/news/explainers

The Guardian. Coronavirus Outbreak. https://www.theguardian.com/world/coronavirus-outbreak

The Washington Post. Coronavirus news and maps. https:/www.washingtonpost.com/world/2020/03/27/coronavirus-latest-news/

Aljazeera. Coronavirus Pandemic News. https://www.aljazeera.com/topics/events/coronavirus-outbreak.html

El Espectador. Coronavirus hoy: ¿Qué están haciendo otros países de América Latina para contener la pandemia?. https://www.elespectador.com/noticias/el-mundo/coronavirus-hoy-que-estan-haciendo-otros-paises-de-america-latina-para-contener-la-pandemiaarticulo-910367

¿Qué está haciendo cada país de América Latina para frenar el nuevo coronavirus?. https://rpp.pe/mundo/actualidad/coronaviruscovid-19-que-esta-haciendo-cada-pais-de-america-latina-para-frenar-el-nuevo-coronavirus-noticia-1252868

Semana. Semana Tendencias Coronavirus. https://www.semana.com/noticias/coronavirus/126948

El Colombiano. Coronavirus en Colombia contra el miedo. https://www.elcolombiano.com/coronavirus-en-colombia-contra-el-miedo

Europapres. Agencia Europa Press https://www.europapress.es/

RFI. Noticias Coronavirus http://www.rfi.fr/es/tag/coronavirus/

CNN Noticias Coronavirus CNN https://cnnespanol.cnn.com/category/coronavirus.

Note: The following official sources and other media were consulted between March 16 and March 27 to identify the actions and strategies defined by the countries.

\section{ALEMANIA}

\section{Fuentes Oficiales}

Federal Ministry of Health. https://www.bundesgesundheitsministerium.de/en/press/2020/coronavirus.html\#c17182

Robert Koch Institute. https://www.rki.de/EN/Home/homepage_node.html

The Federal Government. Together against Corona. https://www.zusammengegencorona.de/

Chancellor and Federal Government. https://www.bundesregierung.de/breg-en/search/998964!search

\section{Otros medios de comunicación}

Deutsche Welle. Coronavirus. https://www.dw.com/en/top-stories/coronavirus/s-32798

Coronavirus en Alemania: últimas noticias. https://www.deutschland.de/es/news/coronavirus-en-alemania-actualizaciones

Noticias Bundesliga. https://www.bundesliga.com/es/bundesliga/noticias/noticias-informacion-actualidad-liga-alemana-3034-2316

Pressemitteilungen. https://www.bundesgesundheitsministerium.de/presse/pressemitteilungen/2020/1-quartal/krisenstab-bmg-bmisitzung-5.html 
Bundesministeriums für Verkehr und digitale Infrastruktur. https://www.bmvi.de/DE/Ministerium/Minister-Staatssekretaere/ministerstaatssektretaere.html

Coronavirus: Jens Spahn trifft Gesundheitsminister der Länder. https://www.youtube.com/watch?v=nm5l-uxSeeM\&feature=youtu.be

Statement von Jens Spahn bei Pressekonferenz vom 19.03.2020. https://www.youtube.com/watch?v=9dQKFImYaY0\&feature=youtu.be

\section{ARGENTINA}

\section{Fuentes Oficiales}

Ministerio de Salud. Coronavirus. https://www.argentina.gob.ar/salud/coronavirus-COVID-19

Gobierno Nacional. Resumen de medidas. https://www.argentina.gob.ar/coronavirus/medidas-gobierno

\section{Otros medios de comunicación}

El Clarin. Coronavirus en Argentina: piden donaciones para ayudar a los que menos tienen. https://www.clarin.com/sociedad/coronavirus-argentina-piden-donaciones-ayudar_0_9O4v1s5nJ.html

Infoabae. Argentina solo recibió ayuda de China para enfrentar la pandemia del coronavirus. https://www.infobae.com/politica/2020/03/22/la-argentina-solo-recibio-ayuda-sanitaria-de-china-para-enfrentar-la-pandemia-del-coronavirus/

RSE Presente. En épocas de coronavirus una ONG contagia solidaridad. https://presenterse.com/en-epocas-de-coronavirus-una-ongque-contagia-solidaridad/

\section{AUSTRALIA}

\section{Fuentes Oficiales}

Coronavirus: COVID-19: Western Australian Government response. https://www.wa.gov.au/organisation/department-of-the-premierand-cabinet/coronavirus-covid-19-western-australian-government-response

Safe Work Australia. https://www.safeworkaustralia.gov.au/doc/coronavirus-covid-19-advice-employers

COVID-19 (Coronavirus) and the Australian border. https://www.homeaffairs.gov.au/news-media/current-alerts/novel-coronavirus

COVID-19 Coronavirus Information for Public Sector Employers. https://www.commerce.wa.gov.au/labour-relations/covid-19-coronavirus-information-public-sector-employers

Departamento de salud Gobierno de Australia. https://www.health.gov.au/news

Health information for western Australia. https://www.healthywa.wa.gov.au/Articles/A_E/COVID-clinics

Conferencia de prensa primer ministro de Australia. https://www.pm.gov.au/media/transcript-press-conference

Actualización medidas primer ministro. https://www.pm.gov.au/media/update-coronavirus-measures

Circular 5/2020 - Licencia COVID-19 y otras flexibilidades laborales. https://www.commerce.wa.gov.au/sites/default/files/atoms/files/ pslr_circular_04_2020.pdf

\section{BRASIL}

\section{Fuentes Oficiales}

Agencia Nacional de Vigilancia Sanitaria. http://portal.anvisa.gov.br/ Ministerio de salud. https://www.saude.gov.br/noticias 


\section{Otros medios de comunicación}

Infoabae. Brasil cerró sus fronteras a europeos y asiáticos por el coronavirus. https://www.infobae.com/america/america-latina/2020/03/20/brasil-cerro-sus-fronteras-a-europeos-y-asiaticos-por-el-coronavirus/

\section{CANADÁ}

\section{Fuentes Oficiales}

Public Health Agency of Canada. https://www.canada.ca/en/public-health/services/diseases/coronavirus-disease-covid-19.html

Página oficial Primer ministro. https://pm.gc.ca/

Página oficial- Gobierno de Canadá. https://www.canada.ca/

\section{CHINA Y HUBEI}

\section{Fuentes Oficiales}

Chinese Center for Disease Control and Prevention. http://www.chinacdc.cn/en/COVID19/

National Health Commission of the People’s Republic of China. http://en.nhc.gov.cn/antivirusfight.html

\section{CHILE}

\section{Fuentes Oficiales}

Plan de Acción Coronavirus. https://www.gob.cl/coronavirus/

Ministerio de Salud. Seguimiento de casos. https://www.minsal.cl/nuevo-coronavirus-2019-ncov/casos-confirmados-en-chile-covid-19/ Ministerio de Relaciones Internacionales. Medidas. https://chile.gob.cl/chile/medidas-de-prevencion-ante-el-nuevo-coronavirus Servicio Informativo del Instituto de Previsión Social. Ministerio del Trabajo. https://www.chileatiende.gob.cl/coronavirus

\section{Fuentes Oficiales}

Ministerio de Salud y Protección Social. Coronavirus. https://d2jsqrio60m94k.cloudfront.net/

Ministerio de salud. https://www.minsalud.gov.co/

Instituto Nacional de Salud. https://www.ins.gov.co/Noticias/Paginas/Coronavirus.aspx

Presidencia de la República. https://id.presidencia.gov.co

Ministerio de Transporte. https://www.mintransporte.gov.co

Aeronáutica Civil de Colombia. http://www.aerocivil.gov.co/

\section{COREA DEL SUR}

Korean Centers for Disease Control and Prevention. http://www.cdc.go.kr/board.es?mid=a30402000000\&bid=0030 


\section{CUBA}

\section{Fuentes Oficiales}

Presidencia de Cuba. Noticias y medidas. https://www.presidencia.gob.cu/es/noticias/

Ministerio de Comercio. Medidas coronavirus. https://www.mincin.gob.cu/content/medidas-de-protecci\%C3\%B3n-tomadas-en-elsector-del-comercio-para-prevenir-cualquier-contagio-0

Ministerio Relaciones Internacionales. Medidas coronavirus. http://misiones.minrex.gob.cu/es/coronavirus

Ministerio de Salud Pública de la República de Cuba. https://salud.msp.gob.cu/

\section{Otros medios de comunicación}

Cibercuba. Mapa del Coronavirus en Cuba. https://www.cibercuba.com/tags/coronavirus-cuba

Infomed, Portal de la Red de Salud de Cuba. http://www.sld.cu/

\section{ESPAÑA}

\section{Fuentes Oficiales}

Alertas en Salud Pública de actualidad. MinSalud España. https://www.mscbs.gob.es/profesionales/saludPublica/ccayes/alertasActual/ nCov-China/home.htm

Instituto de Salud Carlos III. Situación de COVID-19 en España. https://covid19.isciii.es/

Portal de La Moncloa. https://www.lamoncloa.gob.es/Paginas/buscadoravanzado.aspx

Instituto de Mayores y Servicios Sociales. https://www.imserso.es/imserso_02/actualidad/2020/marzo/IM_130154

Ministerio del Interior no a Penitenciarias. www.interior.gob.es

\section{Otros medios de comunicación}

Lista de Medidas del gobierno de El Diario. https://www.eldiario.es

\section{ESTADOS UNIDOS}

\section{Fuentes Oficiales}

Centers for Disease Control and Prevention. https://www.cdc.gov/

Página oficial del coronavirus de CDC. https://www.coronavirus.gov

White house. https://www.whitehouse.gov/

Departamento de Estado. https://travel.state.gov/

Departamento de defensa. https://www.defense.gov/

Asociación de médicos de los Estados Unidos. https://www.ama-assn.org

Gobierno de los Estados Unidos. https://www.usa.gov/ 


\section{ITALIA}

\section{Fuentes Oficiales}

Ministero della Salute. Nuovo coronavirus. http://www.salute.gov.it/nuovocoronavirus

Ministero della Salute. Situazione in Italia. http://www.salute.gov.it/portale/nuovocoronavirus/dettaglioContenutiNuovoCoronavirus.js p?lingua $=$ italiano\&id $=5351 \&$ area $=$ nuovoCoronavirus \&menu=vuoto

Protezione Civile. Emergenza Coronavirus. http://www.protezionecivile.gov.it/

Instituto Superiore di Sanitá. http://www.iss.it/coronavirus

Trova norme salute. http://www.trovanorme.salute.gov.it/norme/dettaglioAtto?id=73532

Guida per prevenire e affrontare lo stigma sociale. http://www.salute.gov.it/imgs/C_17_notizie_4149_0_file.pdf

Aeroporti di Roma. http://www.adr.it/it/web/guest/coronavirus

Governo Italiano Presidenza del Consiglio dei Ministri. http://www.governo.it/it/articolo/comunicato-stampa-del-consiglio-dei-ministri-n-33/14204

Lepidemiologia per la sanità pubblica Istituto Superiore di Sanità. https://www.epicentro.iss.it/

\section{IRÁN}

\section{Fuentes Oficiales}

Ministry of Health and Medical Education. News. http://irangov.ir/cat/509

Ayatollah Khamenei. Official website. http://english.khamenei.ir/

\section{Otros medios de comunicación}

Islamic Republic News Agency. https://en.irna.ir/ y https://es.irna.ir/

Iran Daily. http://www.iran-daily.com/

\section{JAPÓN}

\section{Fuentes Oficiales}

Ministry of Health, Labour and Welfare. About coronavirus Disease 2019. https://www.mhlw.go.jp/stf/seisakunitsuite/bunya/newpage_00032.html Prime Minister of Japan and His Cabinet. Basic responses to COVID2019. http://japan.kantei.go.jp/ongoingtopics/coronavirus_info_e.html

\section{MÉXICO}

\section{Fuentes Oficiales}

Gobierno de México. Comunicados y decisiones. https://coronavirus.gob.mx/noticias/

Dirección General de Epidemiología. Mapa de casos. http://ncov.sinave.gob.mx/mapa.aspx Sistema de Información de la Secretaría de Salud. http://sinaiscap.salud.gob.mx:8080/DGIS/

Instituto Mexicano del Seguro Social. http://www.imss.gob.mx/

Otros medios de comunicación

Diario AS México. Covid-19. https://mexico.as.com/tikitakas/tag/covid_19/a/ 


\section{NORUEGA}

\section{Fuentes Oficiales}

Norwegian Institute of Public Health. https://www.fhi.no/en/id/infectious-diseases/coronavirus/

Ministry of Health and Care Services. https://www.regjeringen.no/en/dep/hod/id421/

\section{REINO UNIDO}

\section{Fuentes Oficiales}

Government UK. Coronavirus. https://www.gov.uk/coronavirus

Coronavirus (COVID-19): UK government response. https://www.gov.uk/government/topical-events/coronavirus-covid-19-uk-government-response

The Health Protection (Coronavirus) Regulations 2020. http://www.legislation.gov.uk/uksi/2020/129/contents/made

Public Health England. https://www.gov.uk/government/organisations/public-health-england

Departamento de salud pública Inglaterra. https://www.gov.uk/government/organisations/department-of-health-and-social-care

Oficina del primer ministro. https:/www.gov.uk/government/organisations/prime-ministers-office-10-downing-street

Ministerio de comunidades y gobierno local. https:/www.gov.uk/government/organisations/ministry-of-housing-communities-andlocal-government

Departamento de trabajo y pensiones. https://www.gov.uk/government/organisations/department-for-work-pensions

Departamento de negocios, energía e industria. https://www.gov.uk/government/organisations/department-for-business-energy-andindustrial-strategy

http://www.legislation.gov.uk/ukpga/1984/22

Foreign Travel Advice. https://www.gov.uk/foreign-travel-advice

Foreign \& Commonwealth Office. https://www.gov.uk/government/organisations/foreign-commonwealth-office

Noticias gobierno de UK. https://www.gov.uk/government/news/

Statutory Sick Pay. Pago estatutario de enfermedad. https://www.gov.uk/statutory-sick-pay

Portal de noticias NHS. https://www.england.nhs.uk/2020/03/nhs-111-online-to-help-people-with-coronavirus/ 


\section{Appendix 2.}

Non-pharmaceutical interventions and number of days in which they were implemented (as March 28, 2020)

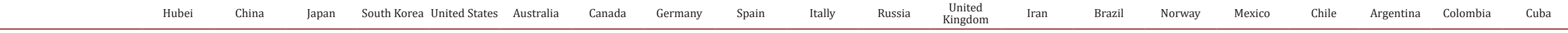

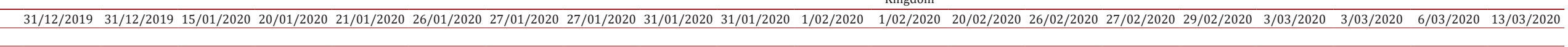

\section{Social distancing at population leve}

Shatatory quarantine throughouthe territory (or part of it

Suspension of face-to-face classes In kindergartens, schools or universities

(1)

Suspension of gatherings

Suspension of non-essential activities

Prohbition of mobility in public or private means of transport

Isolation for 14 days because of attending

es with high influx of people

Isolation because of preng person at high risk of contracting the virus

Travel restrictions

Entry restrictions for foreigners (China)

Entry restrictions for foreigners (other countries)

Border closure for non-essential Traftic

Restritions ond domestic air travels

Restrictions on cruise ships

Case tracking and detectio

Intensive case search (in port of entry and in all territorial entities/provinces)

Contact tracking

Useoftechnology todetectcases, track contats,and notify (eg, thermometers drive-through, app

Labs or additional capabilities

Enabling the use of stadiums and other spaces

Increasing care staff (volunteers, students, retirees, foreigners, humanitarian aid)

Training for doctors

$\begin{array}{llllllll}23 & 24 & & & & & & \\ 23 & 48 & 43 & & & & & \\ 23 & & & & & & 55 & \\ 20 & & & & & 54 & 43 & 39 \\ 20 & & & & & & & 41 \\ 23 & & & & & & \end{array}$

$\begin{array}{lll}38 & 52 & \\ 30 & 48 & 5 \\ 37 & & 5 \\ 49 & & \\ 39 & & \\ 51 & & 35\end{array}$

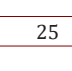

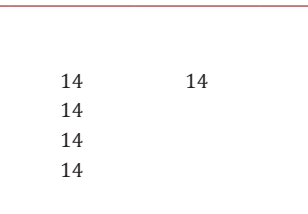

$20-50$

$\begin{array}{lll}34 & \\ 49 & 58 & 33\end{array}$

Strategies for population at ris

Special conditions for over 70 years old people or childre

Special measures for population deprived of liberty

Limiting access to care facilities os how the for the end

Social support

Direct support wi
Tax or credit relie

Food support or other supplies for vulnerable people
Labor or tenant protection measures (in order to avoid layoffs and evictions)

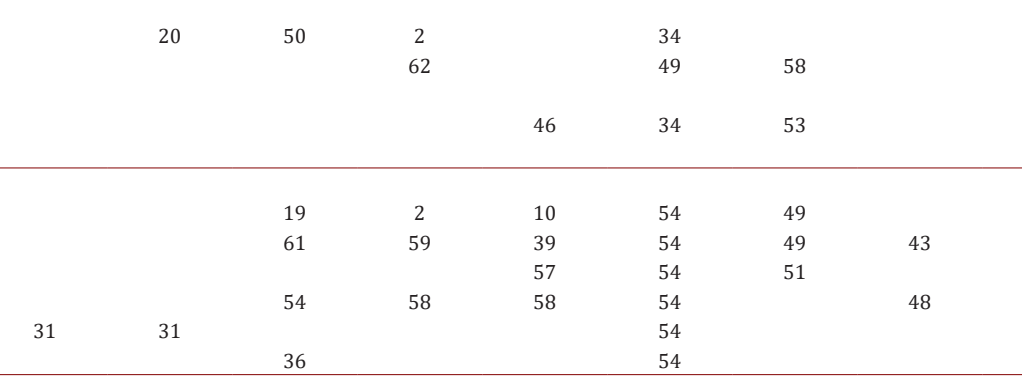

8

$\begin{array}{llllll}20 & 21 & 6 & 6 & & \\ 20 & 21 & 33 & 6 & & \\ 14 & 14 & & 6 & 56 & 44 \\ 27 & 34 & 21 & & & \end{array}$

Colombia Médica hatpil/doi 


\section{Appendix 2. (Continuación)}

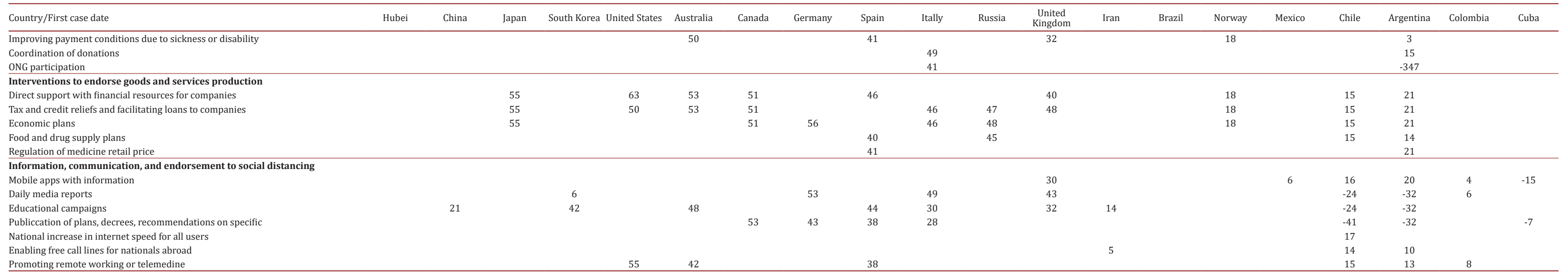




\section{Appendix 3.}

Key findings of studies that addressed the impact of non-pharmaceutical interventions

\section{Non-pharmacological interventions}

Combination of measures
Impact

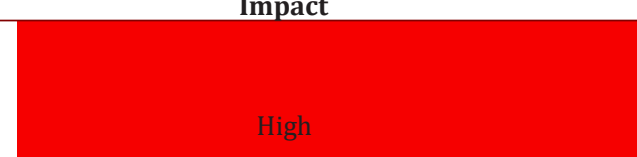

Findings

Two modeling studies (SIR) of COVID-19 infection stablished that strict prevention and early control measures, such as quarantine, social distancing or detention of public transportation service, reduce the infection's contact rate and efficiency, and therefore, are the key on the outbreak. ${ }^{(11)}$

Non-pharmacological measures such as restriction of travels between cities, social distancing and contact reduction, as well as early detection and isolation, have made a substantial reduction of the COVID-19's transmission in Chine. It is estimated that early detection and isolation of the positive cases prevent more infection than restriction in traveling and contact reduction ( 55 versus 2.6 times), but non-pharmacological measures all integrates made the strongest and fastest effect. ${ }^{(12)}$

Without the implementation of non-

pharmacological measures, case numbers of COVID-19 would have increased rapidly in China, 51 times in Wuhan, 92 times in other cities from Hubei and 125 times in other provinces. ${ }^{(12)}$

Implementation times of intervention are also critical. Case's numbers can be drastically reduced in $66 \%, 86 \%$ and $95 \%$, respectively, if NPI could be driven in a week, two week and three weeks before the real time in which they were implemented on the whole country. Also, geographic range of affected areas can be reduced from 308 to 192, 130 and 61 cities, respectively. ${ }^{(12)}$

On most scenarios, tracking of contacts is highly effective and the isolation of positive cases it's enough to control new outbreaks for COVID-19 in three months. Control probability decreases with long delays from the beginning of symptoms to isolation, can determined less cases from contact tracking and increases the transmission before symptoms. ${ }^{(13)}$

The effectiveness of any isolated intervention can be limited, which requires combination of multiple interventions to have a substantial impact on transmission. ${ }^{(10)}$

Optimal mitigation policies (which combine home isolation of suspicious cases, home quarantine of the people who live in the same place as the suspicious case and social distancing of elderly and people at higher risk of severe illness) may reduce the maximum demand of medical care and mortality between $2 / 3$ and a half However, resulting mitigated pandemic probably would lead to hundreds of thousands of deaths and collapsed health services. ${ }^{(10)}$

In total, on a non-mitigated pandemic, we can predict approximately 510.000 deaths in UK and 2.2 million in USA, without taking into account the possible negative effects of a collapsed health system. ${ }^{(10)}$

For a non-controlled epidemic, we can predict that the demand of ICU beds will be exceeded from the second week of April, with a peak in demand 30 times higher than de maximum offer in both countries. ${ }^{(10)}$ 


\section{Appendix 3. (Continuación)}

\section{Non-pharmacological interventions}

Impact

Case isolation

Early detection of cases

Contact tracking

Quarantine of contacts

\section{Findings}

Cities that implement any combination of control measures preventively, before any case of COVID-19, informed 33.3\% (IC 95\%: 11.1-44.4\%) less cases confirmed by laboratory during the first week of (13.0, IC 95\%: 7.1-18.8, n=125), compared with cities who started control measures later (20.6 cases, IC 95\%: 14.5-26.8, $\mathrm{n}=171$; difference between groups, $\mathrm{U}=8197 \mathrm{z}=-3.4, \mathrm{P}<0.01)$. ${ }^{(14)}$

Inside the specific control measures, cities who suspended public transportation within the city and/or closed entertaining places and forbidden public reunions, and made it before, informed less cases during the first week of outbreak. ${ }^{(14)}$

It is estimated that early detection and isolation of cases prevent more infection tan traveling restriction and contact reduction ( 5 vs 2.6 times) but non-pharmacological measurements all together have a stronger and faster impact. ${ }^{(12)}$

It is estimated that early detection and isolation of cases prevent more infection tan traveling restriction and contact reduction (5 vs 2.6 times), but non-pharmacological measurements all together have a stronger and faster impact. ${ }^{(12)}$

On most scenarios, tracking of contacts is highly effective and the isolation of positive cases is enough to control new outbreaks for COVID-19 in three months. Control probability decreases with long delays from the beginning of symptoms to isolation, can determined less cases from contact tracking and increases the transmission before symptoms. ${ }^{(13)}$

Four cohort studies and 15 modeling studies of SARS (Severe acute respiratory syndrome) and MERS (Middle east respiratory syndrome) confirmed the effectiveness of quarantine on individuals that have had close contact with confirmed cases. ${ }^{(11)}$

Only three studies considered the effectiveness of quarantine on hypothetical examples that also modeled the pre-symptomatic infectiousness. The studies are consistent on identifying that quarantine effectiveness depends on a critical way from the biological dynamics of the infectious disease (for example, latent periods and infectious periods) and transmissibility. When the transmissibility is relatively low (basic reproductive number $<2.5$ ), the quarantine may control a disease, even when the infectiousness precedes the symptoms for several days. When transmissibility is high and symptoms come many days after infectiousness, quarantine may be enough. ${ }^{(11)}$

The related evidence with flu pandemics indicates that quarantine of exposed people may delay the peak on local epidemics during the first stages of it, which helps reducing the disease load and also delays the propagation. ECDC

A 14 days quarantine is considered enough to control contact cases of COVID-19, quick identification of cases increases the effectiveness of quarantine measurement. (15)

In Wuhan, if they haven't stablished any traveling restriction on January 23th, cases may have been increased in $118 \%$ (91\% - 172\%), which leads to 13,857 more cases $(10,920-20,574)$, if the prohibition haven't been decreed three days before, it may have reduced cases in 47\% (26\% -58\%), which involves 3,103 less cases $(1,732-3,820)$, cases would have been reduced on a $83 \%(78 \%-89 \%)$ if this measure would have been taken a week before. ${ }^{(16)}$ 


\section{Appendix 3. (Continuación)}

\section{Non-pharmacological interventions}

Cancelling public meetings

Maintenance of social distancing measures, (at least six months after outbreak)
Impact

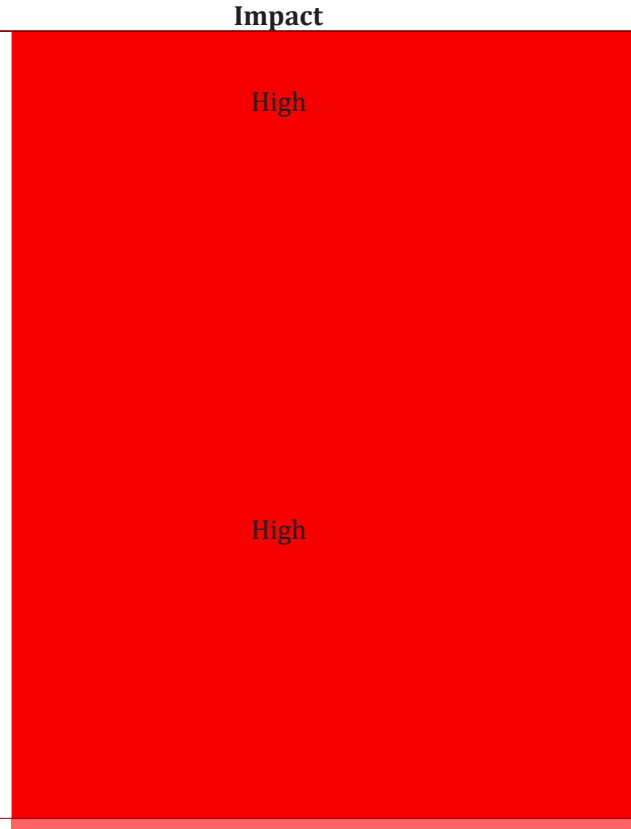

Moderate-High

Moderate

Social distancing of people older than 70 years

Working areas measurements

Moderate

\section{Social distancing}

Low- Moderate

Restriction of travels between cities

Low- Moderate
Low- Moderate

\section{Findings}

Data from seasonal influenza models and pandemic influenza models indicates that, during mitigation stage, cancelling public massive meetings before the epidemic peak may reduce virus transmission. ${ }^{(15)}$

A systematic review from 24 studies found Little but consistent evidence on the fact that influenza transmission occurs among pilgrims on main religious events. Main sports events such as Olympic Games and World Football Cup, detected a marginal increase on incidence of all the infectious diseases, including the flu, with infections limited to competitors and the staff, instead of the crowds or the general community. ${ }^{(17)}$

If the contact with the population resume to normal levels observed on previous years, the suspension on traveling restriction may produce an increasing on the epidemic. Thus, the social distancing may continue during several months. ${ }^{(12)}$

The main challenge in the suppression is that the package of intensive intervention, or something equivalent, effective to reduce the transmission, may be maintained until a vaccine is available (potentially 18 months or so), because it has been predicted that transmission may recover fast if we relax the measures. ${ }^{(10)}$

Self-isolation of individuals with respiratory infection symptoms in one of the most important measures to reduce transmission of diseases and limit the spread of virus on the community during an epidemic. ${ }^{(15)}$

Studies have always considered the contact reduction along with other non-pharmacological measures, ${ }^{(12)}$

Measures on workplaces (flexible work schedules/ shifts for employees, telecommuting, physical distancing) are recommended on people with acute respiratory diseases. ${ }^{(15)}$

Studies have always considered social distancing along with other non-pharmacological measurements. ${ }^{(10-12)}$

Warnings to not travel during epidemics have the goal of reducing the number of infected people during the trip to areas or countries where community transmission is in progress: reducing import risk from affected countries and reducing the transmission among travelers (for example, the line son airport and on airplanes) ${ }^{(15)}$

General restrictions of domestic travels can have a small positive impact on delaying an epidemic, only if they are implemented on early stages. Such restrictions may be considered only during contention stage of a high severity epidemic. ${ }^{(15)}$

While we couldn't contain a higher propagation $\mathrm{f}$ COVID-19, attributed measures to Hubei blocking helped reduced the infection speed and reduce the correlation of national air traffic with COVID-19 cases within China, while interpreting changes observed in time of duplication, may be considered all measures imposed at Wuhan. Data cannot make difference between which strict measures succeeded the most, because the analysis only evaluated the effectiveness of the whole measures. All measures were partially successful and have resulted on delayed propagation of COVID-19 in China. ${ }^{(18)}$

Travel ban from Wuhan delayed the arrival time of COVID-19 to other cities in an average of 2.91 days (IC 95\%: 2.54-3.29 days). More than 130 cities, covering more than half of China's geographic area and population, benefited from the delay. This delay provided additional time to prepare for the arrival of COVID-19 in China but would not have stopped transmission after the infection was exported to new locations from Wuhan. ${ }^{(14)}$ 


\section{Appendix 3. (Continuación)}

\section{Non-pharmacological interventions}

Closing day-cares and schools (low impact)

Quarentine of travelers from affectes areas

Contact reduction

Border closure

Airport case detection procedures
Impact

Low- Moderate

Low

A retrospective cohort study and three modeling studies addressed the effectiveness of quarantine to reduce the transmission from individuals who travelled from high transmission rate areas One of the studies considered evidence of SAR outbreak on 2003 in Taiwan. Results of model show that in the hypothetical scenario where no one would have been quarantined after arriving from a high transmission rate region, there would be 511 additional SARS cases and 70 additional deaths. On data bases, they could track 17 imported cases not quarantined (lost cases and cases before the quarantine implementation). If these 17 imported cases would have been quarantined, 280 SARS cases and 48 deaths may have been avoided. Of the more than 95,000 people in quarantine, only two developed SARS. If these two individuals would have not been quarantined, it may have produced 29 additional cases and 5 deaths. ${ }^{(11)}$

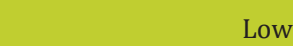

Low

Low

Low

\section{Findings}

Proactive school and daycare closing may be associated with significate cost to society and economy. During contention stage, school closing is not justified. There is no data that back up decision making on proactive school closing in terms of anticipated effectiveness to mitigate COVID-19 epidemic, due to de unknown transmission level of this virus on children. ${ }^{(15)}$

Infection and death numbers avoided with quarantine of travelers from countries with declared outbreaks is substantially lower than quarantine of suspicions or contact cases. ${ }^{(11)}$
LStudies always considered the reduction of contact along with other non-pharmacological ${ }^{(12)}$

According to evidence from modeling studies, mainly related with influenza pandemic, border closure may delay the introduction of virus to a country only if they are full and quickly implemented during early stages, which is only plausible on specific contexts (for example, on small nations, isolated and islands). Therefore, available evidence does not back up the border closure measure that may cause important secondary effects social and economic disorders. ${ }^{(15)}$

Even though some imported cases of COVID-19 have been detected through airport detection procedures, available evidence from all the reviewed publications and the unpublished modeled work made on the ECDC suggests that border control measures are not effective to delay or mitigate a pandemic. This due to the low sensibility of used systems to detect infections lowly symptomatic and its inability to detect cases during incubation stage. ${ }^{(15)}$ 